HENRYK JAROSZEWICZ

Uniwersytet Wrocławski

ORCID: 0000-0003-2840-355X

\title{
KRYTYKA PRÓB EMANCYPACJI ŚLĄSZCZYZNY. PŁASZCZYZNA NAUKOWA (LINGWISTYCZNA)
}

1. Kiedy w połowie pierwszej dekady XXI wieku polski parlament przyjął Ustawe o mniejszościach narodowych $i$ etnicznych oraz o języku regionalnym nadającą kaszubszczyźnie status ,języka regionalnego", wydawało się, że w obrębie polskiej polityki językowej brak już jakichkolwiek poważniejszych punktów spornych, związanych $\mathrm{z}$ wewnętrznym ustrukturyzowaniem polskiego języka narodowego, jego granicami i obszarem funkcjonowania. W momencie, gdy dyskusja nad statusem mowy kaszubskiej de facto stała się już bezprzedmiotowa - wspomniana ustawa pośrednio bowiem uznawała, że mowa Kaszubów nie jest dialektem języka polskiego $^{1}$ - wybuchł kolejny językowy spór, w swojej istocie analogiczny do tego, który jeszcze niedawno dotyczył kaszubszczyzny. Doszło bowiem do zakwestionowaniu poglądu, dotychczas niemal powszechnie przyjmowanego w polskich kręgach badawczych, zgodnie z którym mowa rdzennej, słowiańskiej ludności Górnego Śląska uznawana była za dialekt języka polskiego. Część śląskich środowisk politycznych, lokalnych organizacji kulturalnych i społecznych podjęła działania mające na celu oficjalne usamodzielnienie mowy Ślązaków i nadanie jej statusu drugiego - obok kaszubszczyzny - polskiego języka regionalnego. Pierwsza próba nowelizacji Ustawy o mniejszościach narodowych..., nadająca śląszczyźnie status języka regionalnego została podjęta już w 2007 roku, kolejne w 2010, 2012 oraz w $2016 \mathrm{roku}^{2}$. Za każdym jednak razem, na różnym etapie procedowania, projekty znowelizowanej ustawy były odrzucane przez polski parlament.

1.1. Niepowodzenie działań mających na celu usamodzielnienie się śląszczyzny było przede wszystkim efektem polityki językowej, prowadzonej w Polsce przez

${ }^{1}$ Zgodnie z art. 19.1.2 wspomnianej Ustawy o mniejszościach narodowych ..., język regionalny „różni się od oficjalnego języka tego państwa; nie obejmuje to ani dialektów oficjalnego języka państwa, ani języków migrantów" (Ustawa... 2005).

${ }^{2}$ W styczniu 2018 podjęto kolejną, piątą już próbę nowelizacji Ustawy o mniejszościach narodowych $i$ etnicznych oraz o języku narodowym. Inicjatorką zmiany ustawy, dzięki której etnolekt śląski uzyskałby status języka regionalnego, była posłanka Monika Rosa z partii Nowoczesna (szerz. zob. Zasada 2018). 
elity polityczne sprawujące władzę. Nie można jednak ignorować roli negatywnego stanowiska, jakie wobec projektu samodzielnego języka śląskiego przyjęła Rada Języka Polskiego, czyli gremium, które posiada ustawowy status instytucji opiniodawczo-doradczej w sprawach używania języka polskiego ${ }^{3}$. Kontestacja prób śląskiej emancypacji - obok ścieżki parlamentarno-prawnej - odbywała się również w obszarze szerokiego, publicznego dyskursu, w którym brali udział nie tylko politycy i naukowcy, ale także dziennikarze, publicyści, ludzie sztuki, artyści, działacze społeczni, czy nawet anonimowi członkowie polskiej wspólnoty obywatelskiej, odczuwający potrzebę wypowiedzenia się na temat statusu śląskiej mowy. Wypowiedzi podważające zasadność funkcjonowania śląskiego języka regionalnego spotkać można było w różnego rodzaju przestrzeniach społecznej komunikacji - w prasie codziennej, programach telewizyjnych i radiowych, w internetowych portalach, w publicystyce, w obrębie publikacji naukowych czy w codziennej komunikacji mieszkańców regionu itd. Argumentację krytycznie odnoszącą się do prób emancypacji śląszczyzny podzielić można na taką, która odwoływała się do kwestii polityczno-ustrojowych, społeczno-kulturowych, personalnych i naukowych (lingwistycznych).

1.2. Wśród zarzutów wysuwanych na płaszczyźnie polityczno-ustrojowej centralne miejsce zajmowała teza, mówiąca, że emancypacja etnolektu śląskiego w istotny sposób zagrozi żywotnym interesom polskiej wspólnoty narodowo-państwowej. Wskazywano, że ukonstytuowanie śląskiego języka regionalnego może zostać wykorzystane przez lokalne, śląskie siły separatystyczne jako pierwszy krok na drodze do wyodrębnienia Górnego Śląska z granic państwa polskiego, a Ślązaków z obszaru polskiego etnosu. Przestrzegano również, że zgoda na emancypację śląszczyzny stanowić będzie zachętę do wysuwania analogicznych żądań w innych częściach kraju, co w konsekwencji rozbić możne nie tylko polską spójność terytorialno-etniczną, ale także homogenność całej polskiej przestrzeni komunikacyjnej i polskiego obszaru kulturowego. Obawiano się, że koszty funkcjonowania samodzielnego regionalnego języka śląskiego będą stanowiły dla państwa polskiego bardzo poważne obciążenie, mogące skutkować paraliżem finansów publicznych. Odnosząc się do społecznego wymiaru funkcjonowania samodzielnej śląszczyzny, wskazywano, że jej emancypacja doprowadzić może do wybuchu niepokojów społecznych i konfliktów etnicznych pomiędzy Ślązakami a ludnością nieśląską. W krytycznym dyskursie podnoszono również argumenty o charakterze personalnym - dowodzono, że propagatorzy idei samodzielnego języka śląskiego forsują jego wyodrębnienie jedynie po to, aby osiągnąć osobiste, partykularne korzyści, głównie o charakterze finansowym (szerzej Jaroszewicz 2019). Ostatecznie, w obrębie debaty towarzyszącej próbom usamodzielnienia się etnolektu śląskiego przywoływano argumentację o charakterze naukowym, lingwistycznym. Opierając się przede wszystkim na przesłankach genetyczno-językowych i strukturalno-językowych, a także komunikacyjno-językowych oraz stylistyczno-językowych,

\footnotetext{
${ }^{3}$ Warto zauważyć, że właśnie na negatywne stanowisko Rady powoływano się w oficjalnych, rządowych dokumentach uzasadniających odrzucenie próby ukonstytuowania śląszczyzny jako języka regionalnego (zob. np. Stanowisko Rzadu... 2015).
} 
dowodzono, że projekt samodzielnego i odrębnego od polszczyzny śląskiego języka regionalnego pozbawiony jest racjonalnych podstaw (por. też Michna 2014).

1.3. Celem niniejszej pracy jest prezentacja $\mathrm{i}$ analiza ostatniego z wymienionych wyżej komponentów dyskursu - mowa o krytyce prób emancypacji śląszczyzny, dokonywanej na płaszczyźnie naukowej (lingwistycznej). W rozprawie uwagą zostały objęte nie tylko wypowiedzi językoznawców, ale także popularyzatorów wiedzy o Górnym Śląsku, ludzi kultury i sztuki oraz innych intelektualistów, którzy kwestionowali zasadność usamodzielnienia się mowy Ślązaków, posługując się przy tym argumentami natury lingwistycznej. Wśród przeanalizowanych materiałów gatunkowo największą grupę stanowią artykuły naukowe oraz prasowe wywiady.

Pominięty w niniejszej rozprawie wycinek publicznej debaty, w której poddawano krytyce próby emancypacji śląszczyzny, odnosząc się do argumentacji o charakterze polityczno-ustrojowym, społecznym-kulturowym i personalnym, został omówiony w odrębnej pracy (Jaroszewicz 2019).

2. Podważając zasadność prób kodyfikacji i emancypacji śląszczyzny, często wskazywano, że ukonstytuowanie się śląskiego standardu i jego swobodne funkcjonowanie w przestrzeni publicznej może stać się czynnikiem obniżającym kompetencje komunikacyjno-językowe Ślązaków. Obawiano się, że funkcjonowanie znormatywizowanego etnolektu śląskiego może wprowadzić chaos do językowej komunikacji w regionie, wywołać frustrację wśród użytkowników śląskich gwar, obniżyć ich zaufanie do własnych kompetencji językowych i - w konsekwencji negatywnie rzutować na stosunek Ślązaków do własnej mowy. Tezę taką można odnaleźć w wypowiedziach językoznawczyni Iwony Nowakowskiej-Kempnej:

Stworzenie jednego, sztucznego dialektu śląskiego wprowadzi poważny zamęt, gdyż dzieci i osoby dorosłe, dotąd przekonane, że mówią gwarą śląską - w sensie gwary swojej miejscowości - nagle zrozumieją, że taką gwarą nie mówią, a nowy 'język' jest im obcy i muszą się go nauczyć (Nowakowska-Kempna 2008: 75).

Badaczka szczególną uwagę zwracała na „sztuczność” hipotetycznego języka śląskiego. Pod tym pojęciem lingwistka rozumiała brak tożsamości śląskiego standardu z lokalnymi, śląskimi gwarami:

Uważam, że języka śląskiego jako sztucznego tworu nie powinno się wprowadzać do szkół. Będzie to sztuczny język nieodzwierciedlający mowy dzieci w danej miejscowości w wymowie, gramatyce i słownictwie (przynajmniej w znacznym zakresie) (Nowakowska-Kempna 2008: 75).

Ta sama językoznawczyni akcentowała również, że swobodne funkcjonowanie w śląskiej przestrzeni społecznej skodyfikowanej śląszczyzny szczególnie negatywnie mogłoby wpłynąć na najmłodsze pokolenie Ślązaków. Lingwistka twierdziła, że ukonstytuowanie się języka śląskiego doprowadziłoby do sytuacji, w której śląskie dzieci miałyby kontakt z czterema systemami językowymi. Badaczka - najprawdopodobniej uznając, że posługiwanie się tyloma różnymi kodami językowymi przekracza możliwości intelektualne śląskich uczniów - stawiała również tezę, że wielojęzyczność w praktyce obniżyłaby umiejętności językowo-komunikacyjne młodych Ślązaków: 
Dziecko urodzone na Śląsku będzie (teoretycznie) uczyło się: rodzimej gwary, języka regionalnego śląskiego, języka ogólnopolskiego (aby uczestniczyć w życiu narodowym: gospodarczym i politycznym, kulturalnym i naukowym) oraz angielskiego jako lingua franca naszych czasów. Z czasem może dojść do pomieszania form i rozmówca będzie miał kłopot z komunikacją. (Nowakowska-Kempna 2008: 75).

$* * *$

Częścią fundamentalnej wiedzy o procesach językowej standaryzacji jest pogląd, że nowo tworzony język nie może być tożsamy z gwarami i dialektami, z których wyrasta. Za jedną z konstytutywnych cech każdego języka uznaje się bowiem uzyskanie przezeń niezależności od lokalnego podłoża dialektalno-gwarowego - język to par excellence „nieorganiczny idiom” (por. np. Brozović 1970: 12). Każdy język cechuje się „sztucznością i arbitralnością” (Lubaś 2013: 344), stanowiąc wytwór procesu standaryzacji, byt, którego trzeba się nauczyć - temu między innymi służą lekcje języka ojczystego prowadzone w szkołach (także lekcje języka polskiego). Naturalne jest więc, że dystans pomiędzy językiem a gwarami (z których wyrasta) cechować będzie też śląską materię językową. Tym samym za kuriozalne należy uznać czynienie przez I. Nowakowską-Kempną zarzutu ze „sztuczności” hipotetycznego języka śląskiego i jego braku tożsamości z konkretnymi śląskimi gwarami (por. Lubaś 2013: 342).

Oczywiste jest, że wykształcenie się języka śląskiego przyniesie ze sobą konieczność wyznaczenia w śląskiej przestrzeni językowej podziału na zachowania, które są uznawane za normatywne, poprawne, zalecane oraz pozanormatywne, niepoprawne i niezalecane. $\mathrm{Z}$ punktu widzenia socjolingwistyki nie może to jednak dziwić, pełnienie bowiem przez język funkcji odniesieniowej jest jego kolejną, obligatoryjną właściwością, różniącą go na planie funkcjonalnym od gwar czy dialektów. Nie wydaje się jednak, aby oderwanie się śląskiego standardu od lokalnych gwar oraz - będąca bezpośrednim efektem istnienia języka śląskiego - hierarchizacja zachowań językowych niosły ze sobą „poważny zamęt" lub też „frustracje” użytkowników śląskiego etnolektu. Przestrzeń komunikacyjna każdego języka jest przecież przedzielona cezurą wyznaczającą obszar zachowań normatywnych i nienormatywnych. Rozdźwięk między standardem śląskim i żywą mową śląską oraz nieorganiczność tego pierwszego kodu wpisywać się więc będą w powszechne, normalne schematy przestrzeni komunikacyjnej. Nie wydaje się, aby użytkownicy śląszczyzny, funkcjonujący w przestrzeni komunikacyjnej języka polskiego i przyzwyczajeni do jej normatywnej dwudzielności, mogli być zaskoczeni faktem istnienia rozdźwięku między hipotetycznym śląskim standardem nauczanym w szkole a śląszczyzną używaną w nieoficjalnej, potocznej komunikacji.

Trudno ocenić trafność poglądu I. Nowakowskiej-Kempnej, jakoby wprowadzenie w śląskich szkołach do nauki kolejnego języka (śląskiego) mogło skutkować u uczniów „kłopotami z komunikacją”. Nie są bowiem znane żadne wyniki badań, które dowodziłyby tego, że w tych polskich szkołach, gdzie obok języka polskiego naucza się języków regionalnych lub mniejszościowych (np. na Kaszubach, Opolszczyźnie), młodzież szkolna ma problemy z nauką i „miesza formy”. Dość 
ryzykowne byłoby zakładanie, że dzieci uczęszczające do szkół oferujących naukę języka śląskiego stanowiłyby wyjątek w skali kraju. Na marginesie trzeba zauważyć, że teza I. Nowakowskiej-Kempnej, jakoby nauka wielu różnych języków powodowała „kłopoty z komunikacją”, nieco zaskakuje - w powszechnym przekonaniu to właśnie znajomość różnych języków uchodzi za środek zwiększający kompetencje komunikacyjne i pozwalający na uniknięcie kłopotów w porozumiewaniu się (zwłaszcza w przestrzeni wielojęzycznej).

3. W obrębie krytycznego dyskursu dotyczącego normatywizacji śląszczyzny często wskazywano, że ukonstytuowanie się śląskiego standardu może przynieść negatywne konsekwencje dla witalności i samego funkcjonowania autentycznych śląskich gwar oraz dialektów. W hipotetycznym, skodyfikowanym języku śląskim widziano bowiem rywala żywej, śląskiej mowy, mogącego szybko dokonać ekspansji do tych obszarów komunikacji, które są obsługiwane przez różne śląskie gwary i dialekty. Dowodzono nawet, że w odleglejszej perspektywie czasowej niestandardowe odmiany śląskiej mowy mogłyby ulec całkowitemu wyparciu przez język śląski, czyli kod z samej definicji mający wyższy prestiż aniżeli jakakolwiek śląska gwara czy śląski dialekt. Emancypację śląszczyzny uznawano więc za proces prowadzący do zubożenia - a może nawet zniszczenia - bogactwa i różnorodności śląskiej przestrzeni językowej. Echa takich obaw można odnaleźć m.in. w wywiadzie Heleny Synowiec, który został opublikowany pod wiele mówiącym tytułem „Jeden śląski język odbierze Ślązakom ich godkę?” (Jeden śląski... 2011).

W części prac argumentu o rzekomo dezintegracyjnej roli standardu śląskiego używano w nieco złagodzonej formie. Niektórzy przeciwnicy emancypacji językowej Ślązaków uznawali bowiem, że standardowa śląszczyzna obniży żywotność jedynie tych gwar i dialektów, które zostaną pominięte w procesie selekcji podstawy gramatycznej języka śląskiego. Zakładano bowiem, że norma śląskiego standardu może być tworzona wyłącznie na podstawie jednego kompleksu gwarowego najczęściej w tym kontekście wymieniano gwary gliwicko-toszeckie (Jeden śląski... 2011). W takiej sytuacji wspomniane etnolekty - w naturalny sposób najbliższe standardowemu językowi śląskiemu - uzyskałyby uprzywilejowany status, spychając inne lokalne odmiany śląszczyzny (np. cieszyńską czy opolską) do rangi gwar drugorzędnych, peryferyjnych, prowincjonalnych. Do tego nawiązywała H. Synowiec, która w jednej ze swoich prac zauważała, że „,kodyfikowanie zawsze zmierza do ujednolicenia, uznania cech jednego obszaru gwarowego za główne" (Jeden ślaski... 2011), co w konsekwencji doprowadzić musi do „zmarginalizowania się niektórych [śląskich] gwar" (Jeden śląski... 2011). W podobny sposób o zagrożeniu, jakie kodyfikacja śląskiego standardu niesie dla różnorodności śląskiej przestrzeni językowej pisał też Jan Miodek:

Kapitałem dialektu śląskiego jest jego mozaikowość. Na ten dialekt składa się kilkadziesiąt gwar. Próba kodyfikacji będzie zawsze z krzywdą dla którejś z tych gwar (Jan Miodek... 2011).

Negatywnych konsekwencji kodyfikacji śląszczyzny dopatrywano się nieraz nawet $\mathrm{w}$ samym fakcie, iż regionalny język śląski - z samej definicji pojęcia ,język" - musiałby przyjąć formę skodyfikowanego etnolektu, precyzyjnie opisanego 
i ograniczonego ścisłymi zapisami normatywnymi. Przeciwnicy kodyfikacji śląszczyzny wyrażali pogląd, że jakiekolwiek zawężanie normy, wartościowanie zachowań językowych pozbawi śląską mowę spontaniczności, naturalności, różnorodności, a tym samym ograniczy nie tylko jej możliwości ekspresji i wyrazu, ale także możliwości dalszego jej rozwoju. Myśl taką odnaleźć można m.in. w wypowiedziach prawnika i znanego działacza społecznego Józefa Musioła:

Kodyfikacja zuboży tę wspaniałą różnorodność i bogactwo gwary śląskiej. Każda kodyfikacja coś uściśla, zakreśla pewne ramy, ustanawia granice. I o tyle bogactwo gwary śląskiej będzie uboższe i przestanie się ona swobodnie rozwijać [...]. Gwara nieskodyfikowana, nieograniczona, może różnić się między sobą w swoich wspaniałych odmianach - a to także jej siła i piękno (Musioł 2008: 73).

W obrębie debaty toczonej nad próbami emancypacji języka śląskiego dostrzegano też inny, potencjalny sposób jego kodyfikacji. Zauważano, że standardowa śląszczyzna mogłaby się opierać nie na gruncie jednej, wyselekcjonowanej gwary (jak we wcześniej opisanym modelu standaryzacji), ale na kompromisowej, szerokiej, „interdialektalnej” podstawie, będącej wypadkową wszystkich - a przynajmniej większości - śląskich gwar. Takie rozwiązanie pozwoliłoby uniknąć normatywnego uprzywilejowania jednej, konkretnej gwary i równoczesnego zdeprecjonowania pozostałej części śląskiej przestrzeni językowej, uznanej za obszar niestandardowy. Krytycy procesu usamodzielniania się śląszczyzny dowodzili jednak, że jeśli norma języka śląskiego zawierać będzie elementy właściwe niemal całemu spectrum śląskich gwar, finalnym produktem standaryzacji stanie się „ślaskie esperanto" - nieautentyczny, hybrydalny, sztuczny, językowy zlepek, który nie będzie mógł liczyć na akceptację samych Ślązaków (Mutz 2008: 73). Przed „śląskim esperanto" i jego destrukcyjną rolą - przestrzegała senator i działaczka społeczna Maria Pańczyk-Pozdziej:

Na to powinny być pieniądze, żeby ratować tę różnorodność gwar [śląskich]. To właśnie nas tak pięknie różni na Śląsku. Te gwary są tak różne, że jak przyjeżdżają ci z Opola i ci z Jaworzynki czy Istebnej, to mają kłopot, żeby się wzajemnie zrozumieć. Kodyfikacja śląszczyzny zniszczyłaby to, bo jak się stworzy te [pisownia oryginalna - H.J.] śląskie esperanto, czyli coś sztucznego, to co zostanie z tych gwar (Po naszymu 2012: 37).

Inni badacze także zauważali, że śląski standard, oderwany od autentycznego, konkretnego podłoża gwarowego, wprowadzić może jedynie chaos do przestrzeni komunikacyjnej Górnego Śląska oraz zubożyć kulturową tożsamość i potencjał różnych obszarów tego regionu. Przypuszczenia takie wysnuwał między innymi etnograf i historyk literatury Daniel Kadłubiec, pisząc:

Stworzenie jednego dialektu z różnych gwar [śląskich] byłoby działaniem sztucznym, przypominającym powstanie esperanta. Taki zabieg uważam za mało realny, m.in. dlatego, że osłabiałby wartość kulturową wielu śląskich regionów z żywą gwarą, a zatem także ich specyfikę tożsamościową (Kadłubiec 2008: 69). 
Proces standaryzacji skutkuje zwykle komunikacyjną i społeczną deprecjacją lokalnych gwar i dialektów, na których bazie budowany jest nowy język. Jedną z konsekwencji powołania do życia śląskiego języka regionalnego będzie więc najprawdopodobniej obniżenie prestiżu poszczególnych, lokalnych odmian śląszczyzny i - pośrednio - zmniejszenie ich witalności. Tym samym, po części, można zgodzić się z opinią krytyków idei samodzielnego języka śląskiego, którzy widzą w nim czynnik negatywnie wpływający na różnorodność śląskiej przestrzeni językowej. Trzeba jednak zauważyć, że praktycznie wszystkie gwary i dialekty funkcjonujące na obszarze Polski mają dzisiaj niski prestiż społeczny i witalność, a proces ich wypierania przez standardową polszczyznę sukcesywnie postępuje od dekad na obszarze całego kraju, także Górnego Śląska. Niezależnie więc od tego, czy dojdzie do wykształcenia się śląskiego języka regionalnego, śląskie gwary będą w dalszym ciągu zawężać swoją przestrzeń funkcjonowania i podlegać strukturalnej dezintegracji. Wydaje się, że ukonstytuowanie się śląskiego standardu mogłoby pomóc w zahamowaniu tego negatywnego procesu i zachowaniu - przynajmniej części - oryginalnej, śląskiej materii językowej. Hipotetyczny język śląski, zbudowany na podłożu śląskich gwar mógłby bowiem pełnić rolę swoistego rodzaju ,,przechowalni”, „rezerwuaru” poszczególnych gramatyczno-leksykalnych składników śląskiej przestrzeni językowej. Dzięki realnemu administracyjnemu wsparciu, na jakie mogą liczyć w Polsce języki regionalne (ale nie gwary i dialekty)4, ochrona śląszczyzny zmaterializowanej i zunifikowanej pod postacią śląskiego języka regionalnego byłaby z pewnością łatwiejsza i bardziej skuteczna, aniżeli próby ocalenia całego, wewnętrznie zróżnicowanego kompleksu śląskich gwar. Z takiego punktu widzenia hipotetyczny język śląski jawi się nie jako zagrożenie dla śląskiej materii językowej, ale jako jej efektywny nośnik, narzędzie pozwalające zachować śląską mowę dla następnych pokoleń Ślązaków.

4. W debatach, które towarzyszyły emancypacji mowy Ślązaków, uczestnicy krytycznej narracji bardzo często przywoływali pogląd, zgodnie z którym śląszczyzna to niekwestionowany składnik polskiej przestrzeni językowej - dialekt języka polskiego, jedna z regionalnych, niestandardowych odmian polszczyzny. Sytuowania etnolektu śląskiego w obrębie przestrzeni dialektalnej dokonywano, posługując się argumentami historyczno-językowymi (genetyczno-językowymi) oraz strukturalno-językowymi, rzadziej komunikacyjno-językowymi. Biorąc pod uwagę fakt, że praktyce tej często towarzyszył implicytnie wyrażany pogląd o teleologicznym i zakończonym już rozwoju polskiej przestrzeni językowej ${ }^{5}$, traktowanie śląszczyzny w kategoriach dialektu można było również uznać za przesłankę kwestionującą zasadność jakichkolwiek prób ukonstytuowania samodzielnego języka śląskiego. Uznawano bowiem, że śląszczyzna, raz uzyskawszy status polskiego dialektu,

\footnotetext{
${ }^{4}$ Choć od 1999 r. funkcjonuje Ustawa o języku polskim, w której odnaleźć można zapis głoszący: „ochrona języka polskiego polega w szczególności na [...] upowszechnianiu szacunku dla regionalizmów i gwar, a także przeciwdziałaniu ich zanikowi" (Ustawa... 1999), nie przekłada się to w żaden zauważalny sposób na proces wypierania niestandardowych, terytorialnych odmian językowych przez literacką polszczyznę.
}

${ }^{5}$ O teleologicznej wizji rozwoju językowego zajmująco pisał Artur Czesak (2015: 73). 
posiadła go w sposób trwały, niezbywalny i ostateczny - semel dialectus, semper dialectus.

W obrębie narracji prowadzonej na płaszczyźnie historyczno-językowej odwoływano się zwykle do tradycji polskich badań dialektologicznych i opinii takich lingwistów, jak: Jerzy Bandtkie, Kazimierz Nitsch, Stanisław Rospond, którzy w swoich pracach dowodzili ścisłego związku śląszczyzny z językiem polskim oraz istnienia wspólnego toku rozwojowego mowy śląskiej i pozostałych polskich dialektów. Tym samym naukowe analizy i wyniki badań terenowych - dokonywanych czasem jeszcze w okresie rozbiorowym - traktowano jako niepodważalny argument w dyskusji o statusie etnolektów funkcjonujących w obrębie państwa polskiego na początku XXI wieku. Jako przykład narracji wykorzystującej ten sposób argumentacji, można przytoczyć wypowiedź dialektolog Jadwigi Wronicz. Dla badaczki kluczowym argumentem przemawiającym za współczesną dialektalnością śląszczyzny był fakt, że taki właśnie status przypisano mowie Ślązaków na początku XX wieku w trakcie badań wyznaczających obszar funkcjonowania polskiego obszaru językowego:

Granice między dialektami polskimi a dialektami sąsiednich języków zostały wyznaczone na początku XX w. w oparciu o cechy wewnątrzjęzykowe, na podstawie badań mowy ludności autochtonicznej (Wronicz 2013: 175).

Podobnie jak Wronicz - czyli przywołując tradycyjne, polskie ustalenia badawcze - również inni lingwiści dowodzili dialektalnego statusu śląszczyzny. Andrzej Markowski, przewodniczący Rady Języka Polskiego, w swojej ekspertyzie dotyczącej projektu nowelizacji Ustawy o mniejszościach narodowych $i$ etnicznych... dowodził, że śląszczyzna to bezapelacyjnie komponent polskiej przestrzeni dialektalnej. Głównym argumentem, na który się powoływał, były wyniki prac dialektologicznych, prowadzonych jeszcze w XIX wieku przez Jerzego Bandtkiego i Lucjana Malinowskiego. Odnosząc się do dwójki wspomnianych dialektologów, warszawski badacz pisał:

Już ci pierwsi badacze udowodnili, że gwary śląskie są gwarami języka polskiego, a dialekt śląski, na który się one składają, jest takim samym dialektem języka polskiego, jak dialekt małopolski, wielkopolski i mazowiecki (Markowski 2012: 2) .

W obrębie narracji prowadzonej na płaszczyźnie strukturalno-językowej, przeciwnicy emancypacji śląszczyzny odnosili się często do faktu, że mowa Ślązaków pozbawiona jest w praktyce jakichkolwiek istotnych cech gramatycznych, które nie byłyby obecne w innych polskich dialektach. Podkreślano też znaczący stopień jej leksykalnego pokrewieństwa z pozostałymi komponentami polskiej przestrzeni dialektalnej. Wszystko to świadczyć miało o systemowej niesamodzielności etnolektu śląskiego i jego organicznym, nierozerwalnym związku z pozostałymi polskimi dialektami oraz - w konsekwencji - z samym językiem polskim. Za reprezentatywną można uznać wypowiedź J. Miodka:

Nie ma ani jednej cechy dialektu śląskiego, która by go różniła od innych dialektów, w aspekcie historyczno-językowym [...]. Proszę nie przesadzać z jakąś niewyobrażalną odrębnością

${ }^{6}$ Por. też podobne opinie: Nowakowska-Kempna 2008: 75; Synowiec, Cząstka-Szymon 2008: 80. 
śląszczyzny. W gruncie rzeczy nie ma ani jednej cechy gramatycznej tylko śląskiej. Ani jednej. One są wspólne dla wszystkich dialektów (Jan Miodek... 2011).

Szczególną uwagę systemowo-gramatycznej niesamodzielności śląszczyzny poświęciła jednak J. Wronicz, która w jednej ze swoich prac (Wronicz 2013) przedstawiła wyniki obszernych dialektologicznych komparacji, świadczących o daleko idących powiązaniach etnolektu śląskiego z pozostałą częścią polskiej przestrzeni gwarowo-dialektalnej. Badaczka udowadniała, że nawet najbardziej typowe dla mowy śląskiej cechy gramatyczne występują również w sąsiednich polskich dialektach, a więcej niż połowa (53\%) charakterystycznych dla śląszczyzny leksemów funkcjonuje w obrębie dialektu małopolskiego, wielkopolskiego, mazowieckiego bądź kaszubskiego ${ }^{7}$. Stwierdzając istnienie ścisłych związków pomiędzy etnolektem śląskim i polskimi dialektami J. Wronicz konkludowała swój tekst stwierdzeniem, że:

ani pod względem gramatycznym, ani ze względu na słownictwo Śląsk nie stanowi jednostki odrębnej językowo od innych regionów Polski (Wronicz 2013: 181).

Warto przy okazji podkreślić, że badaczka w swoich pracach kategorycznie stwierdzała, że narzędzi pozwalających na ustalenie statusu określonego etnolektu ('język' vs 'dialekt') szukać należy wyłącznie w ,literaturze naukowej z zakresu dialektologii” (Wronicz 2013: 181), a same badania winno się prowadzić w obrębie dialektologii historycznej poprzez porównywanie struktur leksykalnych i gramatycznych. Zdaniem J. Wronicz, wszelkie przesłanki natury ekstralingwalnej, takie jak: samoświadomość językowej odrębności, posiadanie przez określony etnolekt oficjalnego i prawnego statusu języka, istnienie literatury w nim spisywanej, obecność świadomie kształtowanej ścieżki rozwojowej własnego etnolektu itd., są nierelewantne przy próbie oceny tego, czy dany kod językowy przekroczył już granicę dzielącą dialekt od języka (Wronicz 2013: 175).

\section{$* * *$}

Omówiona wyżej narracja, zgodnie z którą etnolekt śląski stanowi w chwili obecnej dialekt języka polskiego, nie jest możliwa do zaakceptowania w świetle współczesnych teorii językoznawczych. Podstawowym błędem popełnianym przez cytowanych badaczy - J. Miodka, J. Wronicz czy A. Markowskiego - jest hołdowanie poglądowi, jakoby status określonych kodów językowych mógł zostać wyznaczony, wyłącznie w oparciu o fakty natury wewnątrzjęzykowej: genetyczne lub strutkuralne. Współczesne językoznawstwo dowiodło jednak już w latach 60., że nie istnieją intralingwalne kryteria, które „wytrzymywałyby poważniejszą próbę weryfikacji” i w niekwestionowalny sposób pozwalały oddzielić języki od dialektów (Haugen 1980: 169). Na ostateczny układ językowych typologii decydujący wpływ mają bowiem nie właściwości wewnątrzjęzykowe, ale cechy

7 J. Wronicz, ignorując m.in. Ustawę o mniejszościach narodowych i etnicznych... z 2005 r., uznaje język kaszubski za polski dialekt (por. Wronicz 2013: 174, zob. też: Mały słownik... 2010). 
ekstralingwalne. Wśród nich kluczową rolę odgrywa zaś samoświadomość użytkowników, ,wola użytkowników i respekt dla tej woli, wyrażony przez współobywateli” (Czesak 2008a: 22), wtórnie zaś podjęcie przez daną wspólnotę kroków mających na celu kodyfikację własnego etnolektu. Pisał o tym zresztą przed więcej niż dwudziestu laty na łamach miesięcznika „Śląsk” wybitny polski językoznawca Kazimierz Polański:

Problem odróżniania języków od gwar nie jest problemem czysto lingwistycznym, to problem raczej socjologiczny, psychologiczny. W pewnej mierze też polityczny. Nie da się ustalić kryteriów językoznawczych, które pozwalałyby rozróżnić język od gwary. Zasadniczą sprawą jest tu świadomość językowa, która powoduje, że pewna wspólnota językowa w określonym momencie dojrzewa i decyduje się na usamodzielnienie: opracowuje słownik swojego języka, dokonuje kodyfikacji reguł jego użycia, jego pisowni, wyboru alfabetu itd. Od tej chwili można mówić o odrębnym języku (O nauce... 1997: 37).

W świetle takiego ujęcia badawczego pomijanie czynników natury ekstralingwalnej, ignorowanie językoznawstwa instytucjonalnego, niebranie pod uwagę stanowiska wspólnoty komunikatywnej wobec własnego etnolektu itd. uznać należy nie tylko za praktykę uniemożliwiającą poprawne ustalenie statusu określonego etnolektu, ale w dużej mierze utrudniającą samo prowadzenie dyskusji na temat aktualnego kształtu rzeczywistości językowej. Na marginesie można zauważyć, że traktowane w kategoriach żartobliwego, lingwistycznego bon mot stwierdzenie Maksa Weinreicha, iż ,język to dialekt z flotą i armią wojenną”, okazuje się dość trafnie przedstawiać współczesne realia językoznawstwa typologicznego.

Cytowani wcześniej zwolennicy poglądu, jakoby właściwości intralingwalne dawały możliwość wyznaczenia granicy dzielącej język od dialektu, zdawali się również nie dostrzegać faktu, iż badanie toku rozwojowego i komparacja struktur określonych etnolektów niesie ze sobą wiele nierozstrzygalnych, metodologicznych problemów (por. Czesak 2008a: 22). Przede wszystkim trudno ustalić, jaką płaszczyznę języka uznać za kluczową dla ustalenia charakteru relacji istniejącej pomiędzy porównywanymi kodami - gramatyczną czy leksykalną? Jeśli gramatyczną, to czy za relewantne uznać fakty fonetyczne, morfologiczne, fleksyjne, słowotwórcze czy składniowe? Jeśli za najważniejszą uznać warstwę leksyki, to pytaniem jest, czy istotniejsza jest płaszczyzna słownictwa codziennego, czy też leksyki właściwej nadbudowie cywilizacyjnej i specjalistycznym terminologiom? ${ }^{8}$. Gdyby nawet się udało wybrać reprezentatywny obszar dla przeprowadzenie komparacji - bez wątpienia na mocy arbitralnej, subiektywnej decyzji - nie wiadomo, jaki odsetek różnic, względnie podobieństw, miałby konstytuować określony kod jako samodzielny język, względnie dialekt. Wskazany przez J. Wronicz fakt, że więcej niż połowa charakterystycznych dla śląszczyzny leksemów funkcjonuje w obrębie dialektu małopolskiego, wielkopolskiego, mazowieckiego lub kaszubskiego, można bowiem traktować zarówno jako dowód nierozerwalnego związku śląszczyzny z innymi

8 Warto w tym miejscu wskazać, że zdaniem Witolda Mańczaka, w obrębie typologii genetyczno-językowej cechą wyznaczającą granice między etnolektami jest zbieżność leksykalna, nie zaś gramatyczna - „Moim zdaniem tym, co najtrwalsze w języku, są pierwiastki i dlatego racjonalna klasyfikacja genealogiczna powinna opierać się wyłącznie na słownictwie” (Mańczak 1996: 173). 
polskimi dialektami (aż 53\% p o krew i én s tw a leksykalnego), jak i świadectwo samodzielności i odrębności śląszczyzny (aż 47\% o drę b n oś c i leksykalnej). Trudno zanegować poczynione przez J. Miodka spostrzeżenie, że w obrębie śląszczyzny brak jakiejkolwiek istotniejszej cechy gramatycznej, która nie funkcjonowałaby równolegle w dialekcie małopolskim, względnie wielkopolskim, mazowieckim albo w kaszubszczyźnie. To jednak, co dla J. Miodka stanowi dowód niesamodzielności etnolektu śląskiego, można równie dobrze uznać za jego szczególny wyróżnik. Śląszczyzna może być bowiem postrzegana jako wyjątkowy w skali kraju etnolekt, będący oryginalną i niepowtarzalną syntezą polskich cech dialektalnych (por. Tambor 2014: 44).

Genetyczne pokrewieństwo określonych kodów, manifestujące się posiadaniem częściowo wspólnego zasobu leksyki i cech gramatycznych, również nie może być traktowane jako uniwersalne kryterium pozwalające wyrokować o współczesnych relacjach tychże etnolektów oraz o ich aktualnym statusie. Bliskość genetyczna stanowi bowiem jedynie dowód na to, że określone kody posiadały w określonym wycinku swojej przeszłości wspólny tok rozwojowy - podlegały tym samym lub podobnym procesom i zjawiskom gramatyczno-leksykalnym. Zawiązanej niegdyś wspólnoty nie można jednak traktować jako ponadczasowej i automatycznie oraz bezrefleksyjnie uznawać jej za aktualną także w chwili obecnej (por. Wyderka 2011: 3). Języki, dialekty czy gwary są przecież żywymi systemami komunikacji, które podlegają w czasie naturalnym procesom konwergencyjnym i dywergencyjnym, a żadnego momentu w ich rozwoju nie można uznać za „statyczny punkt finalny, efekt teleologicznego rozwoju” (Czesak 2015: 73). Dawne właściwości społeczno-strukturalno-funkcjonalne tychże kodów nie mogą być automatycznie transponowane do opisu dzisiejszej rzeczywistości językowej. Status określonego etnolektu, klasyfikowanego bądź jako 'język', bądź 'dialekt' nie jest przecież wartością constans, niezmienną i daną ,raz na zawsze”. Historia językoznawstwa zna wszakże przypadki, kiedy etnolekt do niedawna niemal powszechne uważany za dialekt innego języka, w przeciągu kilku dekad zaczął być traktowany jako pełnoprawny, samodzielny język (casus języka ukraińskiego, białoruskiego czy macedońskiego).

Za kryterium umożliwiające odróżnienie języka od dialektu nie może być też uznany stopień wzajemnej zrozumiałości, istniejącej pomiędzy porównywanymi kodami (por. Miodek 2012: 2). Naukowo nieweryfikowalna i ponownie niosąca z sobą nierozstrzygalne problemy metodologiczne jest teza mówiąca, że jeśli osoby posługujące się dwoma różnymi etnolektami mogą się ze sobą porozumieć, to ich kody należy uznać za język i podrzędny wobec niego dialekt (względnie za dwa dialekty jednego języka), a jeśli porozumienie nie jest możliwe, to zestawiane ze sobą kody są dwoma różnymi językami (lub dwoma dialektami przynależnymi do różnych języków). Poszczególne komunikaty mogą się bowiem różnić tak dużą liczbą cech (np. użytym kanałem, poruszaną tematyką, czasem dostępności dla odbiorcy lub tempem wypowiadania, sposobem artykulacji lub rodzajem pisma i użytego alfabetu, objętością lub czasem trwania, stopniem złożoności gramatycznej, przynależnością stylistyczną itp.), że nie sposób inaczej aniżeli na mocy subiektywnej, arbitralnej decyzji wybrać reprezentatywną próbkę - „wzorcowy” 
rodzaj komunikatu, którego poziom zrozumienia będzie decydował o ocenie globalnej relacji między oboma kodami. Brakuje też jasnych, naukowych kryteriów, które pozwoliłyby ustalić, jaka część komunikatu musi być zrozumiała, aby cały komunikat móc uznać za zrozumiały. Być może należałoby brać pod uwagę nie procentową ilość zrozumiałego tekstu, ale stopień zrozumienia głównego przekazu zawartego w danym tekście ${ }^{9}$. Aby uświadomić bezużyteczność kryterium zrozumiałości, można wskazać, że każdy przeciętny Polak rozumie sens wypowiadanych zdań: „Это мой сын”, „То moj sin”, albo fraz „hladna voda” i „krátká noha”. Trudno jednak na bazie tego faktu dowodzić, że języki rosyjski, czarnogórski, słoweński i czeski (z których pochodziły przykładowe frazy) to dialekty języka polskiego $^{10}$.

Tezę o dialektalnym statusie śląszczyzny podważa ostatecznie fakt, że w pierwszych dekadach XXI wieku mowa Ślązaków ,,przekroczyła granice definicyjne dialektu" (Wyderka 2014: 112). W polskich, encyklopedycznych opracowaniach z zakresu językoznawstwa - Encyklopedii języka polskiego (Encyklopedia... 1994), Encyklopedii językoznawstwa ogólnego (Encyklopedia... 1993) czy Słowniku terminologii językoznawczej (Gołąb, Heinz, Polański 1968) - dialekt jest definiowany jako mowa niewykształconej ludności wiejskiej, charakterystyczna dla określonego regionu kraju, ograniczona funkcjonalnie, spotykana głównie w nieoficjalnych kontaktach. Przeciwstawia się ją językowi literackiemu (ogólnemu), który - w odróżnieniu od dialektu - upowszechniany jest przez szkołę, media i administrację, funkcjonuje w kontaktach oficjalnych, cechuje się polifunkcjonalnością i ścisłą normą opisaną w słownikach oraz gramatykach, posiada określony dorobek literacki i, ostatecznie, stanowi środek komunikacji właściwy warstwom wykształconych (por hasła: 'dialekt', 'gwara', 'język literacki’, 'język ogólny', 'dialekt kulturalny', 'zróżnicowanie języka narodowego’ w wymienionych wyżej pracach encyklopedycznych). Biorąc pod uwagę przedstawione wyżej społeczno-funkcjonalno-strukturalne właściwości dialektu, nietrudno zauważyć, że dzisiejszej śląszczyzny nie da się już ,wepchnąć” w jego ramy definicyjne. Obecna mowa Ślązaków jest bowiem kodem, którym posługuje się wysoki odsetek ludności miejskiej, w tym warstwy wykształcone, inteligenckie ${ }^{11}$. Istnieje bez wątpienia zróżnicowana literatura śląska, obejmująca gatunkowo zarówno powieści, opowiadania, dramaty, jak i poezję, eseistykę. Obecne są też liczne przekłady literatury światowej na śląski, a nawet całościowy przekład Nowego Testamentu dokonany w 2017 roku przez Gabriela Tobora (Nowy testamynt... 2017). Na rynku funkcjonuje kilkanaście elementarzy, gramatyk, rozmówek i podręczników do nauki

\footnotetext{
${ }^{9}$ Warto w tym miejscu podkreślić kolejną komplikację, a mianowicie fakt, że zrozumiałość jest w gruncie rzeczy wartością stopniowalną, nie zaś binarną: „Między tym, co całkowicie niezrozumiałe, i tym, co całkowicie zrozumiałe, rozciąga się szeroka strefa pośrednia, tego, co zrozumiałe częściowo" (Haugen 1980: 178).

${ }^{10}$ Odrębną kwestią jest też problem z wyborem podmiotu mającego decydować o stopniu zrozumiałości określonego komunikatu - w kontekście śląskim jasne jest bowiem, że Polak żyjący na Górnym Śląsku będzie w zdecydowanie większym stopniu rozumiał komunikat stworzony w etnolekcie śląskim, aniżeli jego rodak mieszkający na Podlasiu czy Pomorzu.

${ }^{11}$ Por. np. Grybosiowa 1998 za: Lubaś 2013: 316; Lubaś 2013: 337.
} 
śląskiego, a także liczne słowniki mowy śląskiej, w tym słowniki dwujęzyczne ${ }^{12}$. W 2009 roku zespół śląskich twórców oraz aktywistów pod kierownictwem Jolanty Tambor ustalił w Cieszynie główne zasady ortografii śląskiej (tzw. ślabikŏrzowy szrajbōnek - szerzej Tambor 2009), respektowane przez pisarzy związanych z Silesia Progress oraz Narodową Oficyną Śląską, czyli największymi wydawnictwami publikującym śląską literaturę. Od tej pory na rynku ukazało się przeszło pięćdziesiąt pozycji książkowych wydanych zgodnie z przyjętymi w Cieszynie regułami pisowni. Mowa śląska funkcjonuje oczywiście w przestrzeni publicznej - w lokalnych rozgłośniach radiowych, stacjach telewizyjnych, prasie, w Internecie. Wykorzystywana jest w reklamach ulicznych, radiowych i telewizyjnych przez koncerny i firmy o światowym zasięgu działania, takie jak: Volkswagen, Coca Cola, Samsung, Credit Agricole (por. Hadasz 2017). Obecna jest śląska wersja Wikipedii (przeszło 52 tys. artykułów hasłowych), śląskojęzyczna nakładka w portalu społecznościowym Facebook, część telefonów komórkowych firmy Samsung ma możliwość włączenia śląskojęzycznego menu. Od 2018 roku działa informacyjny portal internetowy wachtyrz.eu, gdzie duża część artykułów publikowana jest po śląsku. Od kilku lat funkcjonuje też profesjonalne biuro tłumaczeń ponaszymu.pl, oferujące usługi translatorskie na język śląski oraz prowadzące internetowe kursy gŏdki. Biorąc wszystkie te fakty pod uwagę, należy przyjąć, że traktowanie śląszczyzny jako etnolektu o identycznym statusie co np. dialekt wielkopolski lub małopolski jest całkowicie nieuprawnione.

Odrębną kwestią, wymagającą wnikliwszej analizy jest to, w jakim stopniu czynniki pozajęzykowe mogą wpływać na forsowaną współcześnie tezę, zgodnie z którą śląszczyzna to niesamodzielny etnolekt, dialekt języka polskiego. Nietrudno bowiem dostrzec pewne paralele pomiędzy tym, jak znacząca części polskich środowisk naukowych odnosiła się jeszcze niedawno do języka kaszubskiego oraz tym, jak obecnie odnosi się do śląszczyzny ${ }^{13}$.

${ }^{12}$ Bardzo szczegółowy zarys współczesnego piśmiennictwa śląskiego przedstawił Czesak (2015: 101-196).

${ }_{13}$ Jak wiadomo, w niektórych kręgach polskiego językoznawstwa dość długo funkcjonowało nieformalne założenie, że oficjalna zgoda na uznanie kaszubszczyzny za odrębny język sprzeczna będzie z polską, narodową racją stanu. Akceptacja językowego statusu mowy Kaszubów traktowana była w kategoriach „wspierania propagandy niemieckiej”, ,występowania przeciw własnemu narodowi, który Niemcy chcieli wynarodowić" (Mańczak 1995: 41). Pewne elementy takiej postawy charakteryzowały zresztą nawet największych polskich językoznawców, w tym Kazimierza Nitscha. Można w tym miejscu przywołać słowa Alfreda Zaręby, który następująco opisywał stosunek K. Nitscha do kaszubszczyzny: „Otóż mówiąc o kaszubszczyźnie K. Nitsch jednoznacznie twierdził, że uznawanie tego (bardzo zresztą odrębnego, choć silnie genetycznie z polskimi dialektami lądowymi związanego) dialektu polskiego za odrębny język jest m.in. wynikiem dalekosiężnej antypolskiej polityki zaborców (Prus i carskiej Rosji), polityki, której celem było wykazanie światu, że Kaszuby do Polski nie należą, bo mówią przecież nie po polsku. W zamyśle zaborców tkwiła idea odcięcia Polski od Bałtyku" (Zaręba 1987: 85). Jeżeli więc teza o dialektalnym statusie kaszubszczyzny była traktowana w niektórych polskich środowiskach naukowych jako oręż w walce o Kaszuby i strategiczny dostęp Polski do morza, być może analogiczna strategia narracji występowała (występuje) także w przypadku mowy Ślązaków. Śląszczyzna, uznawana za dialekt, „mowę Rejów i Kochanowskich”, niezbywalny i immanentny składnik języka polskiego, służyć by mogła legitymizacji praw narodu polskiego do obszaru Śląska i znajdujących się tam bogactw naturalnych (por. zagadnienie „poprawności patriotycznej” w: Lubaś 2013: 343; por. też Czesak 2008a: 21). 
4. Jednym z najczęściej przywoływanych argumentów lingwistycznych, mających dowodzić błędności podejmowanych na Górnym Śląsku działań emancypacyjnych, był fakt istnienia daleko idącej heterogeniczności śląskiej przestrzeni językowej. Wskazywano, że na przeszkodzie stworzenia jednego, powszechnie akceptowanego na całym Górnym Śląsku standardu stoi nieusuwalna, gramatyczno-leksykalna różnorodność śląskich gwar, z góry skazująca na niepowodzenie jakiekolwiek językowe idee unifikacyjne. Jako reprezentatywne można przytoczyć opinie Jana Miodka, który w ankiecie rozpisanej przez miesięcznik „Śląsk” definitywnie odrzucał możliwość kodyfikacji śląskiej mowy:

Wobec niezwykłego zróżnicowania poszczególnych gwar śląskich w każdym detalu fonetycznym - zupełne nie wyobrażam sobie skodyfikowania dialektu śląskiego (Miodek 2008)

oraz Iwony Nowakowskiej-Kempnej, która w tej samej ankiecie pisała:

Uważam stworzenie jednego wspólnego dialektu śląskiego za niemożliwe, trudno mi powiedzieć, co mogłoby być podstawą kodyfikacji. Istnieje znacząca różnica między gwarami cieszyńskimi, w których brak mazurzenia, i gwarami centralno-północnymi, z pochodzenia małopolskimi, obecnie małopolsko-śląskimi, w których występuje mazurzenie (Nowakowska-Kempna 2008: 75).

W bardzo podobnym tonie o różnorodności gwarowej Śląska pisało też wielu innych krytyków idei stworzenia samodzielnego, śląskiego języka regionalnego (por. np. Pańczyk-Pozdziej 2008; Synowiec, Cząstka-Szymon 2008; Szołtysek 2008: 79).

$* * *$

Zaprezentowany wyżej pogląd, jakoby znaczące, wewnętrzne zróżnicowanie określonego obszaru językowego (w tym wypadku śląskiego) uniemożliwiało wykształcenie w jego obrębie skodyfikowanego standardu, uznać należy za nietrafny. Kluczowym czynnikiem, decydującym o sukcesie procesu standaryzacji, nie jest bowiem stopień strukturalnej zbieżności poszczególnych komponentów obszaru językowego, dla którego planuje się wyodrębnić wspólną, wzorcową, normatywną odmianę. W literaturze socjolingwistycznej wskazywano, że zdecydowanie ważniejszy od tej cechy intralingwalnej jest czynnik ekstralingwalny - wolincjonalny. Akcentowano, że jeżeli użytkownicy zróżnicowanych komponentów jednego obszaru językowego wykażą się odpowiednią determinacją oraz wystarczającą wolą kompromisu, właściwie żadne przeszkody natury strukturalno-językowej nie są w stanie uniemożliwić realizacji projektu jednego, wspólnego standardu. W sytuacji jednak, gdy woli takiej zabraknie, nawet najmniejsze różnice mogą stanowić wystarczający pretekst dla zerwania (lub niepodejmowania) działań integracyjnych. Kwestię tę poruszał zresztą w jednej ze swoich prac Einar Haugen:

Grupa, która czuje się solidarna ze wspólnotą, pragnie przezwyciężyć duże nawet różnice językowe; brak poczucia solidarności może natomiast uruchomić procesy alienacji grupy nawet wtedy, gdy różnice językowe są niewielkie (Haugen 1980: 190). 
Na marginesie można zauważyć, że poprawności takiego założenia i decydującej roli czynników wolincjonalnych dowiodły losy niedawno rozbitej serbsko-chorwackiej wspólnoty językowej, w minimalnym przecież stopniu zróżnicowanej gramatycznie oraz leksykalnie.

5. W obrębie krytycznego dyskursu prowadzonego na płaszczyźnie lingwistycznej często przywoływano fakt systemowo-funkcjonalnych ograniczeń śląszczyzny. Uznawano, że mowa Ślązaków może znaleźć zastosowanie wyłącznie w komunikacji nieformalnej, potocznej. Zakładano też istnienie swoistego rodzaju „sprzężenia zwrotnego" - prostym i ograniczonym w swoich możliwościach (systemowo-funkcjonalnych) etnolektem posługiwać się miała społeczność ludzi prostych, o ograniczonych potrzebach i możliwościach (intelektualnych, cywilizacyjnych itp.).

Jako przykład takiego rozumowania można podać wypowiedź autorów Słownika gwar śląskich, Barbary i Adama Podgórskich:

Język śląski, choć na to twierdzenie wielu się obrusza, nie nadaje się do kontaktów oficjalnych, urzędowych, publicznych. Jest to język rodzin i tradycyjnych środowisk chłopskich oraz robotniczych (Podgórska, Podgórski, 2008: 76-77).

Jeszcze dobitniej aniżeli Podgórscy, o ,prostocie” Ślązaków i śląskiej mowy mówił Jan Miodek w wywiadzie udzielonym Teresie Semik:

Gwara [śląska] jest mową chłopską, prostych ludzi. Wariantem literackim śląszczyzny jest polszczyzna, tak będę mówił do śmierci, choćbyście tu mieli o to do mnie straszne pretensje (Semik 2010).

Warto przy tym zauważyć, że badacz ograniczoność i ułomność śląszczyzny traktował jako cechę stałą i niezmienną. W innych swoich wypowiedziach Miodek wykluczał bowiem możliwość jakiejkolwiek intelektualizacji śląszczyzny, kwestionując próby wykorzystywania jej do komunikowania treści o większej złożoności intelektualnej, czy też konstruowania komunikatów o charakterze oficjalnym, urzędowym. W cytowanym już wywiadzie lingwista twierdził:

Nie można $w$ gwarze śląskiej wypowiedzieć abstrakcyjnych, filozoficznych treści? [Teresa Semik] Nie można, bo brzmi to groteskowo (Jan Miodek... 2011).

$* * *$

Analizując cytowane wyżej wypowiedzi, łatwo zauważyć, że sam tylko rozwój najnowszej literatury śląskiej całkowicie zdezaktualizował tezę, jakoby mowa Ślązaków zdatna była wyłącznie do tworzenia komunikatów nieoficjalnych, prostych w formie i treści. W obliczu faktu opublikowania kilku zbiorów esejów filozoficznych po śląsku (np. Kadłubek 2008, Kik 2015), śląskiego przekładu aforyzmów Franza Kafki (Ślōnski Kafka 2016), tłumaczenia epigramatów Angelusa Silesiusa (Dante... 2014: 61-68) czy w końcu wspomnianej wcześniej, całościowej translacji Nowego Testamentu (Nowy Testamynt... 2017), wypowiedź J. Miodka o niemożności skonstruowania po śląsku ,wypowiedzi abstrakcyjnych, filozoficznych” jawi się wyłącznie 
jako dowód tego, że rozwój językowy toczy się czasem niezależnie od prognoz lingwistów.

Inną kwestią, którą należy szczególnie zaakcentować w kontekście komentowanych wypowiedzi Miodka czy Podgórskich, jest to, że nauce nie są znane etnolekty, które wskutek swoich właściwości gramatyczno-leksykalnych byłyby trwale niezdolne do wyrażania intelektualnie bardziej złożonych treści oraz do funkcjonowania w sferze publicznej. Wszystkie przecież języki, nawet te, które cechują się dzisiaj wyjątkowo złożoną strukturą gramatyczno-leksykalną i nieograniczoną polifunkcjonalnością, wywodzą się bezpośrednio z dialektów (gwar), czyli etnolektów, które z perspektywy np. dzisiejszego literackiego języka polskiego jawią się jako kody o niewielkim stopniu złożoności gramatycznej, leksykalnej, stylistycznej itp. Tym samym kategoryczne stawianie tezy, że śląszczyzna - wskutek istnienia jakiejś bliżej niesprecyzowanej, immanentnej, wewnętrznej nieusuwalnej ułomności - jest ex definitione skazana na bycie narzędziem komunikacji, mogącym wyrażać wyłącznie treści proste w ustach ,prostych ludzi”, ponownie należy uznać za przejaw mylnie postawionej naukowej diagnozy.

5.1. Dowodem na funkcjonalno-stylistyczne ograniczenia etnolektu Ślązaków miały być istniejące, śląskie przekłady literatury światowej oraz teksty śląskie, właściwe stylowi naukowemu i publicystycznemu. W części wypowiedzi stawiano bowiem tezę, że użycie w literackich translacjach oraz innych tekstach o wyższym stopniu intelektualizacji i oficjalności „mowy chłopskiej, prostych ludzi”, względnie ,języka rodzin i tradycyjnych środowisk chłopskich oraz robotniczych" mimowolnie wywołuje efekt ludyczny i skutkuje rozbawieniem czytelnika. O takich właśnie reakcjach wspominał cytowany wcześniej J. Miodek, twierdząc, że forsowanie śląskiej mowy w obrębie tekstów literackich skutkuje wykształceniem się komunikatów „groteskowych”, a nawet takich, które sprawiają, że słuchające ich osoby „rechoczą ze śmiechu” (Jan Miodek... 2011):

Kiedy ks. prof. Józef Tischner pisze o Platonie po góralsku, odbieram to pierońsko sztucznie. Mówię po śląsku „pierońsko sztuczne”, przy całym szacunku dla Tischnera [Jan Miodek]. [...] Można tłumaczyć Biblię na śląski, a „Ojcze nasz...” - nie? [Teresa Semik] Można w żartach przetłumaczyć nawet Biblię i powiedzieć: 'Archanioł Gabryjel przyfurgoł do frelki Maryjki i Jej pedzioł, co bydzie miała karlusa, kierymu nado imie Jezus...’. Można przy tym rechotać ze śmiechu, jak rechoczą moi koledzy z Warszawy, Wrocławia czy Poznania, kiedy im takie śląskie zdania wygłaszam [J.M.] [...]. Czy gwary śląskie sq w stanie udźwignać role języka urzędowego, jak tego chca zwolennicy kodyfikowania ślaszczyzny? [T.S.] Jeśli powiem po śląsku „ewidentny”, ,permanentny” zamiast 'ewidentny' i 'permanentny', to będzie groteska. [J.M.] (Jan Miodek... 2011).

W podobny sposób jak J. Miodek, do prób użycia śląszczyzny poza obszarem potocznej, nieoficjalnej komunikacji odnosił się w swoich starszych pracach również Bogusław Wyderka. Jego zdaniem zastosowanie etnolektu śląskiego w telewizyjnych programach informacyjnych wywołałoby efekt humorystyczny, kabaretowy:

Trudno sobie wyobrazić, że w telewizji spiker po śląsku mówi o tarczy antyrakietowej. Jest poważna obawa, że wyszedłby z tego kabaret (Oddzielmy gwarę... 2008). 
Nieco obszerniej kwestią funkcjonalno-stylistycznego ograniczenia śląszczyzny oraz immanentnej ludyczności tekstów tworzonych w obrębie tego kodu zajęła się Anna Momot. Badaczka w jednej ze swoich prac dowodziła wprost, że śląskie translacje literatury światowej naruszają zasadę decorum i wywołują efekt komiczny. Wśród śląskich tekstów, stanowiących - jej zdaniem - dobry przykład nieodpowiedniości treści i formy znalazły się m.in. fragmenty wiersza Kawafisa oraz pieśni Dantego w przekładzie Mirosława Syniawy. Językoznawczyni w swojej pracy zestawiała tłumaczenia śląskie $\mathrm{z}$ istniejącymi przekładami polskimi (m.in. Edwarda Porębowicza i Zbigniewa Kubiaka), uznając, że translacje M. Syniawy ,zdają się brzmieć mniej poetycko” i są po prostu ,zabawne, komiczne” (Momot 2016: 69). Lingwistka, idąc krok dalej niż J. Miodek, twierdziła też, że komizm i niezamierzona ludyczność śląskich tłumaczeń wynikały nie tylko z faktu użycia nieadekwatnych, kolokwialnych pseudoodpowiedników dla oryginalnych form właściwych stylowi artystycznemu. W jej opinii, ,śmieszność” tłumaczeń M. Syniawy, ale też Marka Szołtyska czy Zbigniewa Kadłubka wypływała bowiem z samego faktu użycia śląszczyzny w formie pisanej:

\begin{abstract}
Niewątpliwie większość tekstów nazywanych 'śląskimi tłumaczeniami' jest zabawna - niezależnie od intencji twórców utwory te zdają się pełnić przede wszystkim funkcję ludyczną. W przypadku translacji bajek Tuwima czy Brzechwy jest to oczywiste i naturalne, jednak w pozostałych sytuacjach to niejako efekt uboczny potraktowania śląskiej mowy jako poliwalentnej odmiany języka. Dzieje się tak zapewne dlatego, że sama próba odczytania zapisu gwarowego wywołuje śmiech odbiorców (docelowo głównie Ślązaków), nieprzyzwyczajonych do lektury tekstu pisanego (w dodatku artystycznego) ich codzienną, potoczną mową (Momot 2016: 69-70; zob. też Mowa śląska... 2011: 24).
\end{abstract}

Nie ulega wątpliwości, że śląski język literacki jest dopiero na początkowym etapie swojego rozwoju, a repertuar jego środków wyrazu z pewnością jest znacząco węższy aniżeli języków o tak długiej tradycji literackiej jak polszczyzna. Stylistyczne usterki czy potknięcia są ze zrozumiałych względów nieuniknione i nietrudne do odnalezienia w śląskich dziełach translatorycznych, tekstach o charakterze publicystycznym czy popularnonaukowym. Trudno jednak zgodzić się z praktyką przekreślania en bloc dorobku współczesnych śląskich literatów i tłumaczy, zwłaszcza że w literaturze naukowej trudno odnaleźć poważne, stylistyczne studia nad najnowszym piśmiennictwem śląskim. Spotykane w części prac wartościowanie śląskich przekładów literatury światowej, czy też śląskojęzycznych tekstów o charakterze oficjalnym (urzędowym, naukowym, informacyjnym itd.) jako 'groteskowych', 'komicznych', ‘śmiesznych', ‘zabawnych’ z pewnością nie można uznać za właściwe naukowej refleksji. Klasyfikowanie określonych jednostek leksykalnych, czy nawet całych systemów językowych, za pomocą kryteriów tak niewymiernych i nieweryfikowalnych, właściwe jest raczej potocznemu, subiektywnemu porządkowaniu rzeczywistości.

Wydaje się, że wspomniany przez J. Miodka „rechot”, będący ponoć reakcją na śląskojęzyczny komunikat, wynika w głównej mierze $\mathrm{z}$ faktu istnienia pewnych 
głęboko zakorzenionych w polskiej kulturze przekonań, stereotypów związanych z gwarami oraz dialektami. Mowa o postrzeganiu niestandardowych odmian języka jako kodów funkcjonalnie ograniczonych i niedorozwiniętych, do pewnego stopnia prymitywnych, pozwalających przekazywać jedynie treści o niskim stopniu intelektualizacji i niewysokim poziomie złożoności formalnej. Tego typu kodami, co bardzo ważne, posługiwać się mają wyłącznie niskie warstwy społeczne, ludność niewykształcona, upośledzona ekonomicznie, niepartycypująca w kulturze wysokiej, zwykle wiejska („,chłopi”), będąca często w społeczeństwie obiektem żartów, wykpiwania ${ }^{14}$. Dość łatwo taką odmianę językową uznać za mało „poważny” system komunikacji, traktować „,z przymrużeniem oka”, a nawet przyjąć wobec niej postawę protekcjonalnej pobłażliwości. Jeżeli postrzegany w ten sposób kod zaczyna jednak wykraczać poza „koncesjonowaną” przestrzeń komunikacji (folklor, kabaret oraz nieoficjalne kontakty, zwłaszcza domowe) oraz wykształcać w swoim obrębie teksty właściwe kulturze wysokiej, budzić to może całkowicie zrozumiały dysonans poznawczy, konfuzję, dezorientację. Jednym z naturalnych sposobów radzenia sobie z takim dysonansem jest często śmiech i ironia - w śląskim kontekście aktualizowana przez przywoływany wcześniej ,rechot” warszawskiego, poznańskiego czy wrocławskiego językoznawcy.

Na subiektywne odczuwanie ,śmieszności” śląszczyzny bez wątpienia wpłynął fakt, że do niedawna etnolekt ten obecny był w mediach (zwłaszcza ogólnopolskich) niemal wyłącznie w specyficznym typie programów telewizyjnych i radiowych. Pomijając reportaże i rzadkie, okolicznościowe transmisje koncertów śląskich zespołów pieśni i tańca, przeciętny mieszkaniec Polski miał okazję słyszeć śląszczyznę głównie w produkcjach o charakterze kabaretowo-komediowym. Mowa przede wszystkim o różnego rodzaju przeglądach i widowiskach, w których brały udział kabarety pochodzące z Górnego Śląska, wykorzystujące w trakcie występów śląski etnolekt (odpowiednio ,zaadaptowany” dla potrzeb widowni i samego występu). Do najbardziej znanych ,śląskojęzycznych” zespołów kabaretowych, stosunkowo często goszczących w telewizji zaliczyć można Kabaret Rak, Kabaret Młodych Panów oraz Masztalskich. Obecność śląszczyzny w mediach, prócz wspomnianych widowisk kabaretowych, związana była także z bardzo popularnym serialem komediowym Święta wojna, emitowanym przez II Program Telewizji Polskiej w latach 2000-2009 (obecnie można ten serial oglądać m.in. na antenie TV Silesia). Akcja tej obszernej produkcji komediowej (322 odcinki) rozgrywała się w Katowicach, w środowisku rodowitych Ślązaków, główną oś akcji stanowiły zaś perypetie filmowej rodziny Huberta i Anny Dwornioków (granych przez Krzysztofa Hankego i Joannę Bartel). Etnolekt śląski, którym posługiwali się aktorzy, stanowił materiał szczególnie nośny w komizm, bardzo często wykorzystywany do tworzenia zabawnych gagów. Jako dość prawdopodobna jawi się więc hipoteza, że kabaretowo-komediowy profil telewizyjnych i radiowych produkcji wpływał na utrwalanie się

${ }^{14}$ Taką percepcję gwar i dialektów (kodów społecznie stygmatyzujących swoich użytkowników) utrwalają zresztą wypowiedzi polskich językoznawców i innych osób publicznych, którzy nawet współcześnie określają np. mowę Ślązaków mianem „mowy chłopskiej, prostych ludzi” (Jan Miodek - zob. Semik 2010). 
stereotypowego wyobrażenia śląszczyzny, uznawanej za środek komunikacji niezdatny do wyrażania treści ,poważnych”. Równocześnie z tym wyobrażeniem tworzyło się zarazem przekonanie, że mowa Ślązaków dobrze się sprawdza w obrębie funkcji ludycznych języka, na przykład jako tworzywo „wiców”, żartobliwych monologów, komediowych dialogów itp. Nie ulega też wątpliwości, że śląszczyzna w odbiorze społecznym zaczęła być do pewnego stopnia postrzegana jako kod o naturalnych właściwościach komicznych, stanowiąc odmianę językową, na której dźwięk przeciętny Polak mimowolnie oczekuje usłyszenia żartu, czegoś „śmiesznego" (por. Nawarecki 2008).

Warto też zauważyć, że traktowanie jakiegoś wyrażenia, czy nawet całego etnolektu w kategoriach 'śmiesznego' (ale też 'ładnego', 'brzydkiego' itp.) może być czasem konsekwencją funkcjonowania określonych stereotypów narodowych lub etnicznych. Mowa rzecz jasna o dość prostym mechanizmie przeniesienia określonych, utrwalonych wyobrażeń i ocen dotyczących jakiejś grupy etniczno-narodowej na język tejże społeczności. Nieprzypadkowo przecież uznawanie przez wielu Polaków języka czeskiego za ,śmieszny” idzie w parze ze stereotypowym wyobrażeniem Czecha jako osoby mało poważnej, lubiącej się śmiać, niezaprzątającej sobie głowy egzystencjalnymi problemami, unikającej sytuacji ryzykownych, lubiącej wygodę, piwo i dobre jedzenie - „myśląc o Czechach, myślimy o narodzie śmiejącym się. Są weseli i sympatyczni” (Gołąbek, Kulesza, Rygiel 2013: 266; por. też: Jak Polacy... 2012: 3-4; Szczepańska 2013: 289-292). Omawiana tu percepcja śląszczyzny jako mowy ,śmiesznej”, analogicznie do przypadku czeskiego, może być więc interpretowana jako pochodna stereotypowego wyobrażenia Ślązaka, czyli „śmiesznej” odmiany Polaka. Stereotypowy mieszkaniec Górnego Śląska to wszakże osoba nieco „ociężała”, nieumiejąca mówić prawidłowo po polsku, przedkładająca nad kulturę wysoką swoją własną, niską i plebejską, lubiąca piwo i ,krupnioki”, skupiona na ciężkiej pracy, zwykle w kopalni (Tambor 2008: 84-92). Ślązak, podobnie jak Czech, to także osoba lubiąca żartować, przy czym cechuje go proste, ludowe i rubaszne poczucie humoru - „Stereotypowy Ślązak lubi godać wice i suchać wiców" (Tambor 2008: 94).

Komentując zagadnienie „śmieszności” śląskich tekstów, warto ostatecznie zwrócić uwagę, że za takim sposobem wartościowania najprawdopodobniej kryła się również subiektywna, polonocentryczna percepcja rzeczywistości językowej. Przykładu takiej postawy można się dopatrywać w wypowiedzi J. Miodka, który traktował w kategoriach ,groteski” użycie potencjalnych śląskich form: 'ewidyntny', 'permanyntny', wyprowadzonych od właściwych literackiej polszczyźnie leksemów 'ewidentny' oraz 'permanentny' (Jan Miodek... 2011). Trudno jednak inaczej - aniżeli jako przejaw polonocentryzmu - interpretować fakt, że choć wszystkie człony par: 'ewidyntny' i 'ewidentny' oraz 'permanyntny' i 'permanentny’ są zapożyczeniami (formy polskie wiązać należy z łacińskimi permanere, evidens), to zarzut „groteskowości” J. Miodek stawia jedynie formom śląskim. Można przypuszczać, że w oczach badacza polskie zapożyczenia przed byciem ,groteskowymi” chroni ich „polskość”, przynależność do literackiej polszczyzny.

5.2. W narracji przeciwników kodyfikacji języka śląskiego wielokrotnie podnoszono argument, że funkcjonowanie śląszczyzny w innej sferze aniżeli prywatna, 
nieoficjalna ustna komunikacja, nie ma większego sensu. Wskazywano bowiem, że na obszarze Górnego Śląska w sferze publicznej z powodzeniem funkcjonuje literacka polszczyzna, którą - co ważne - potrafią się posługiwać wszyscy Ślązacy. Akcentowano, że literacki język polski dzięki swojej szerokiej poliwalencji w pełni zaspokaja wszelkie potrzeby komunikacyjne mieszkańców całego regionu. Konkludowano, że kodyfikacja śląszczyzny i używanie jej - na przykład w obrębie stylu administracyjnego, naukowego czy artystycznego - jest całkowicie niepotrzebne.

Opinię taką można odnaleźć w wypowiedzi znanego dramaturga Stanisława Mutza, który kwestionował funkcjonowanie śląszczyzny w obszarze języka nauki (,Żeby poznać zasady mechaniki kwantowej, nie muszę sięgać do śląskiej literatury" - Mutz 2008: 73) oraz stawiał pod znakiem zapytania sensowność wykorzystania mowy Ślązaków do przekładania dzieł literatury światowej:

Są dwie szkoły: jedni uparcie twierdzą, że po śląsku można tylko 'fulać i fanzolić' (najchętniej o kluskach i modrej kapuście), drudzy (szkoła prof. Kadłubka i dr. Szołtyska): równie dobrze rozprawiać o Wittgensteinie, czytać i przekładać Biblię, Iliadę i Odyseę, dzieła Kafki czy Prousta. Czy ma sens thumaczenie Prousta czy Kafki na śląski? Ja jestem w stanie zrozumieć Prousta i Kafkę bez śląskiego (Mutz 2008: 73).

Podobnie jak S. Mutz, także H. Synowiec negatywnie odnosiła się do możliwości użycia śląszczyzny w języku nauki. Warto jednak podkreślić, że badaczka za zbyteczne uznawała nawet samo funkcjonowanie śląszczyzny w formie pisanej:

Widzi pani profesor potrzebę skodyfikowania śląskiej godki? [Teresa Semik] Nie widzę takiej potrzeby. Nie wiem, jaką funkcję miałaby pełnić wersja pisana gwary, która ze swej istoty jest odmianą mówioną. Jak dotąd gwara dobrze służy domowym, lokalnym, nieoficjalnym kontaktom. Półoficjalnym też. Jakie to gatunki wypowiedzi Ślązak miałby zapisywać? Pisma do urzędu? [...] [Helena Synowiec] Czy zdaniem pani profesor gwara śląska, w jej obecnym kształcie, może stużyć jako język wyktadowy, urzędowy, obstugiwać kontakty oficjalne? [T.S.] $\mathrm{Na}$ wykładach z dialektologii może się pojawić, ale nie wyobrażam sobie lekcji, na przykład, chemii, podczas której nauczyciel próbuje wyjaśniać gwarą zachodzące procesy. Nie zna słowa probówka, więc mówi weź flaszeczka, poszelontaj... Nie widzę potrzeby, żeby gwara obsługiwała także sferę języków specjalistycznych. Nie wytworzyła terminologii, bo nie było takiej potrzeby [H.S.] (Jeden śląski... 2011).

W jednym ze swoich wywiadów także J. Miodek eksplicytnie wyznaczał właściwy i pożądany - jego zdaniem - zakres użycia śląszczyzny. Mowa śląska, w opinii wrocławskiego badacza, powinna obsługiwać jedynie obszar komunikacji mówionej, szczególnie zaś aktywności o charakterze folklorystycznym, na przykład śpiewy:

Ślazacy chcący kodyfikować swój język powinni udać się do prof. Jana Miodka, té Ślązaka [N.N.]. - I usłyszą: chłopy, tego nie da się zrobić! - mówi profesor. - Mówcie po śląsku, śpiewajcie, organizujcie konkursy gwary, ale dajcie sobie spokój z urzędowym językiem [Jan Miodek] (Czy ślaszczyzna... 2003).

W najradykalniejszy sposób sferę użycia etnolektu śląskiego proponowała zawęzić M. Pańczyk-Pozdziej, której zdaniem mowa śląska powinna funkcjonować wyłącznie w przestrzeni prywatnej, w domostwie konkretnego użytkownika śląszczyzny: 
Jeśli ktoś ma silną potrzebę mówienia po śląsku, to może tę potrzebę pokazać w domu (Po naszymu 2012).

\section{$* * *$}

Formułowane przez przeciwników emancypacji śląszczyzny stanowisko, zgodnie z którym używanie mowy śląskiej poza sferą folkloru oraz obszarem nieformalnej, ustnej komunikacji jest niepotrzebne, bezzasadne i zbędne, najprawdopodobniej dowodzi dwóch faktów: ignorowania pozakomunikacyjnych funkcji spełnianych przez każdą kategorię ludzkiej mowy (język, dialekt, gwara itd.) oraz niezrozumienia specyfiki funkcjonalno-strukturalnej kodu w randze języka regionalnego.

Socjolingwistyka dawno już dowiodła, że choć prymarną cechą mowy ludzkiej jest umożliwienie porozumiewania się członkom określonej wspólnoty, język - paralelnie do komunikacyjnej - spełnia wiele innych istotnych funkcji pozakomunikacyjnych: (auto)identyfikacyjną, integracyjną, delimitacyjną, kulturotwórczą, symboliczną, prestiżową, emocjonalną itd. Ludzka mowa to bez wątpienia jedno z głównych narzędzi identyfikacji grupowej i jednostkowej (autoidentyfikacja), środek pozwalający określonej jednostce włączyć się do jakiejś społeczności (i ją opuścić), element umożliwiający człowiekowi odnaleźć własne miejsce w gąszczu otaczających go tradycji, kultur i wierzeń, medium łączące taką jednostkę z przodkami, rodakami i zamieszkiwanym miejscem, wskaźnik indywidualnej oraz grupowej samooceny (i samookreślenia), podstawowe narzędzie tworzenia kultury niematerialnej, ważny komponent sfery symbolicznej określonej wspólnoty (obok wierzeń, zwyczajów, określonych tradycji materialnych, hymnu, flagi, własnej waluty, wojska itp.). Język ostatecznie - zarówno w skali grupowej, jak i indywidualnej - stanowi jeden z podstawowych sposobów manifestowania i budowania swojej tożsamości. Tym samym zalecenia, aby za pomocą swojej ojczystej mowy śpiewać i bawić widzów na folklorystycznych imprezach albo ograniczyć jej użycie wyłącznie do czterech ścianach własnego domostwa uznać można za dalece niestosowne, a być może nawet za niebezpiecznie bliskie postulatom, które wcielano w życie w państwach kolonialnych, totalitarnych i innych, nierespektujących praw mniejszości i reguł demokracji. Odnosząc się do wyrażanych wcześniej opinii, można się zgodzić, że polszczyzna całkowicie zadowalająco wypełnia $\mathrm{w}$ tym regionie funkcję poliwalentego $\mathrm{i}$ uniwersalnego medium komunikacji - zwłaszcza że jest językiem, który znają wszyscy mieszkańcy Górnego Śląska. Oczywiste jest jednak i to, że język polski nie jest w stanie (w pełni) zaspokoić innych, pozakomunikacyjnych potrzeb Ślązaków ${ }^{15}$. Truizmem będzie więc stwierdzenie, że tylko paralelne funkcjonowanie polszczyzny i śląszczyzny

\footnotetext{
${ }^{15}$ Warto zauważyć, że konsekwentne postrzeganie języka wyłącznie przez pryzmat posiadanych przezeń funkcji komunikacyjnej kwestionuje nie tylko sens kodyfikacji śląskiej mowy i wprowadzenia jej do oficjalnego użycia, ale także - z czego krytycy emancypacji śląszczyzny nie zdają sobie chyba sprawy podważa zasadność posiadania praw językowych przez jakiekolwiek mniejszości narodowe i etniczne zamieszkujące obszar Polski. Nie ulega przecież wątpliwości, że - tak jak ma to miejsce w przypadku Ślązaków - również obywatele Polski narodowości niemieckiej, litewskiej czy czeskiej władają biegle literacką polszczyzną.
} 
może uczynić sferę językową regionu kompletną i społecznie satysfakcjonującą. Rugowanie mowy śląskiej z przestrzeni publicznej, utrudnianie jej rozwoju, zamykanie w rezerwacie koncesjonowanych użyć folklorystyczno-ludycznych lub ściśle prywatnych, prowadzić może do językowo-komunikacyjnych patologii, które prędzej czy później odcisną się negatywnie na relacjach społecznych w regionie.

Jak już wspomniano, opór przeciwko ukonstytuowaniu mowy śląskiej jako języka regionalnego wynikać może również z błędnego rozumienia samej idei języków regionalnych i postrzegania ich jako „rywali” języków państwowych. Hipotetyczny regionalny język śląski traktowany jest czasem jako zagrożenie dla polszczyzny, kod, który „zabierze” jej użytkowników albo wyprze ją z użycia w określonych obszarach komunikacji. Tymczasem języki regionalne - biorąc pod uwagę zapisy zawarte w Europejskiej karcie języków regionalnych i mniejszościowych oraz w Ustawie o mniejszościach narodowych $i$ etnicznych oraz o języku regionalnym - są etnolektami fakultatywnymi, pomocniczymi, posiadając charakter komplementarny, nie zaś opozycyjny wobec ogólnokrajowego standardu językowego. Użytkownicy języków regionalnych posługują się nimi obok, a nie zamiast państwowego języka urzędowego - jasne jest więc, że z chwilą nadania śląszczyźnie statusu języka regionalnego, Ślązacy w Polsce nie przestaną mówić po polsku, a śląskie dzieci nie zaczną bojkotować lekcji języka polskiego w polskich szkołach. Warto też podkreślić, że użycie języka regionalnego jest radykalnie ograniczone terytorialnie - za ,rywala" polszczyzny nie można uznać śląszczyzny, która mając status języka regionalnego, mogłaby funkcjonować jako fakultatywny, urzędowy język jedynie w kilkunastu, może kilkudziesięciu śląskich gminach (biorąc pod uwagę dane z Narodowego Spisu Powszechnego z 2011 roku).

Wydaje się też, że w ferworze dyskusji nad próbami usamodzielnienia się śląszczyzny, krytycy procesów emancypacyjnych często zapominają o fakcie, że głównym zadaniem, jakie stoi przed językami regionalnymi - w tym przed regionalnym językiem śląskim - jest pełnienie roli narzędzia umożliwiającego efektywny rozwój lokalnej kultury (także tej wysokiej) oraz funkcjonowanie w roli medium, służącego manifestowaniu i tworzeniu regionalnej tożsamości. Biorąc to pod uwagę, jasne się staje, że śląszczyzna, jako język regionalny, nie będzie musiała wykształcić w swoim obrębie pełnego wachlarza stylów funkcjonalnych i osiągnąć gramatyczno-leksykalnego rozwoju właściwego rozwiniętym, ogólnokrajowym standardom. Tym samym sensu istnienia śląskiego języka regionalnego w żaden sposób nie można uzależniać od obecności (i przydatności) hipotetycznych, pisanych po śląsku pism procesowych, podręczników astronomii rentgenowskiej, studiów z genetyki lub rozpraw dotyczących struktur algebraicznych itp.

6. Podsumowując rozważania nad krytyką prób emancypacji śląszczyzny, można postawić hipotezę, że omawiana wyżej postawa kontestacji (realizującej się również na płaszczyźnie lingwistycznej) pośrednio może być skutkiem niedoceniania lub ignorowania znaczenia i zakresu przemian, które w ostatnim ćwierćwieczu objęły Górny Śląsk - a także samych efektów tychże transformacji.

Nie ulega bowiem wątpliwości, że po przemianach ustrojowych z przełomu lat 80. i 90. ubiegłego wieku oraz po upadku przemysłu ciężkiego, który niemal przez dwa wieki kształtował główne toki rozwoju cywilizacyjnego Górnego Śląska, 
doszło do „przebudzenia” społeczności śląskiej, która otwarcie i w nieskrępowany sposób zaczęła mówić o swojej etnicznej i kulturowej odrębności, a także podjęła wysiłek zweryfikowania i zredefiniowania swojej tożsamości oraz przewartościowania dotychczasowych form uczestnictwa w życiu gospodarczym, społecznym i politycznym ${ }^{16}$. Efektem wzrostu grupowej samoświadomości był nie tylko rosnący opór przeciwko stereotypowym wyobrażeniom Górnego Śląska i samych Ślązaków, ale też próby upodmiotowienia i zmiany statusu własnej grupy społecznej oraz zamieszkiwanego regionu. Do roli sztandarowych urosły dwie idee - idea 'autonomii Górnego Śląska', nawiązująca tradycjami do okresu II Rzeczpospolitej i ówczesnego autonomicznego województwa śląskiego oraz idea 'narodu' lub, w złagodzonej wersji, 'narodowości śląskiej'.

Suma transformacji, które zaszły w sferze tożsamościowej, świadomościowej, mentalnej, gospodarczej i ekonomicznej, przełożyła się na przemiany kulturowe całego Górnego Śląska. Na początku XXI wieku tutejsza, lokalna kultura zdecydowanie wykroczyła poza dotychczasowe, wąskie ramy kultury niskiej, plebejskiej, ludowej i ludycznej, nasyconej treściami folklorystycznymi. Obserwując jedynie rozwój najnowszego śląskiego piśmiennictwa, można zauważyć, że dynamika tworzenia się nowych regionalnych wzorców kulturowych i wyznaczania nowych, cywilizacyjnych toków rozwojowych jest bardzo wysoka. Mając na uwadze wszystkie te transformacje - niektóre o charakterze rewolucyjnym - nie można się dziwić, że na Górnym Śląsku pojawił się projekt stworzenia samodzielnego, regionalnego języka.

W nowej rzeczywistości, w jakiej znalazł się po zmianach ustrojowych Górny Śląsk i sami Ślązacy, jasne się bowiem stało, że tworzywem nowej i nowoczesnej śląskiej kultury regionalnej nie mogła być już dłużej śląszczyzna w swoim dotychczasowym kształcie. Niskoprestiżowy etnolekt, gwara niosąca ze sobą liczne pejoratywne konotacje (,mowa chłopska, prostych ludzi”), wyśmiewana i do niedawna rugowana z życia publicznego, funkcjonalnie upośledzona, pozbawiona normy, materialnie utrwalona jedynie w obrębie wąskiego korpusu tekstów o charakterze ludowym lub/i ludycznym przestała już zaspokajać potrzeby Ślązaków. W nowych realiach funkcję efektywnego, lokalnego narzędzia kulturotwórczego predestynowany jest spełniać jedynie nowoczesny śląski język regionalny - prestiżowy i skodyfikowany kod, nauczany w szkołach, obecny w administracji lokalnej, mediach, teatrze, wykorzystywany do tworzenia wartościowych dzieł literackich, mogący liczyć na ochronę i wsparcie państwa.

W takim ujęciu emancypacja śląszczyzny i hipotetyczne podniesienie jej do rangi języka regionalnego jawi się nie jako jedno z możliwych, fakultatywnych rozwiązań, które może zostać podjęte przez podmioty polskiej polityki językowej, ale jako naturalna konsekwencja przemian mających miejsce na Górnym Śląsku i w samej Polsce po 1989 roku. Kwestionowanie dzisiejszych językowych, emancypacyjnych dążeń Ślązaków można zaś uznać za dowód niezrozumienia lub braku akceptacji dla przemian politycznych, społecznych, kulturowych i cywilizacyjnych, które u schyłku XX wieku objęły nie tylko Górny Śląsk, ale i samą Polskę.

${ }^{16}$ Bardzo trafnie o przyczynach i przebiegu „śląskiego przebudzenia” pisał w kilku swoich pracach krakowski badacz Artur Czesak (zob. np. 2008a: 18-19; 2008b). 


\section{Bibliografia}

Brozović D., 1970, Standardni jezik, Zagreb: Matica hrvatska.

Czesak A., 2008a, Mowa Górnoślązaków - nowe otwarcie?, w: Śląsko godka. Materiaty z konferencji 'Ślasko godka - jeszcze gwara, czy jednak już język' z 30 czerwca 2008 r., red. J. Tambor, Katowice, Wydawnictwo Gnome, s. 15-30.

Czesak A., 2008b, Różnice językowe w kontekstach politycznych i humanistycznych, „Kultura i polityka. Zeszyty naukowe WSE" 2/3, s. 189-210.

Czesak A., 2015, Współczesne teksty śląskie na tle procesów językotwórczych i standaryzacyjnych współczesnej słowiańszczyzny, Kraków, Księgarnia Akademicka.

Czy ślaszczyzna to polszczyzna? 2003, Wywiad z Janem Miodkiem, „Polityka” 30 (2411), 26.07.2003, s. 12, https://archiwum.polityka.pl/art/czy-slaszczyzna-to-polszczyzna,380175. html [1.02.2018].

Dante i inksi, 2014, Poezyjǒ w tumaczyniach Mirosława Syniawy, Kotórz Mały, Silesia Progress.

Drenda J., 2017, Gramatyka gwary górnośląskyj [regiónu katowicko-bytómskygo], Siemianowice Śląskie, Text Partner.

Encyklopedia językoznawstwa ogólnego, 1993, red. K. Polański, Wrocław, Zakład Narodowy im. Ossolińskich.

Encyklopedia języka polskiego, 1994, red. S. Urbańczyk, Wrocław, Zakład Narodowy im. Ossolińskich.

Gołąb Z., Heinz A., Polański K., 1968, Stownik terminów językoznawczych, Warszawa, Państwowe Wydawnictwo Naukowe.

Gołąbek E., Kulesza J., Rygiel B., 2013, Sąsiedzi: stereotyp Czecha na podstawie badań społecznych i źródet internetowych (prace badawcze studentów ATH), „Świat i Słowo” 2 (21), s. $265-271$.

Greń Z., 2009, Problematyka językowa w górnośląskich i zaolziańskich dyskusjach internetowych, w: Językowy świat Stowian. Zjawiska, interpretacje, znaki zapytania. Księga jubileuszowa na 70-lecie Profesora Włodzimierza Pianki, red. J. Mindak-Zalewska, I.M. Doliński, Warszawa, s. 75-100.

Greń Z., 2014, Tożsamość ślaska: etniczna czy regionalna?, w: Konstrukcje i dekonstrukcje tożsamości. Narracja i pamięć III, red. E. Golachowska, A. Zielińska, Warszawa, s. 251-267.

Hadasz A., 2017, Reklamy po śląsku: światowe koncerny, ale i szkoty i uczelnie zabiegaja o Śląaków, „Dziennik Zachodni”, 23.07.2017, http://www.dziennikzachodni.pl/ wiadomosci/katowice/a/reklamy-po-slasku-swiatowe-koncerny-ale-i-szkoly-czy-uczelnie-zabiegaja-o-slazakow,12296565/ [1.02.2018].

Haugen E., 1980, Dialekt, język, naród, w: Język i społeczeństwo, red. M. Głowiński, przeł. K. Biskupski, Warszawa, Czytelnik, s. 169-194.

Jak Polacy postrzegaja swoich sasiadów, 2015, CBOS. Komunikat z badań nr 124/2015, http://www.cbos.pl/SPISKOM.POL/2015/K_124_15.PDF [1.02.2018].

Jan Miodek: Dyskusja o języku ślaskim w piśmie jest żenująca, 2011, Wywiad Teresy Semik z Janem Miodkiem, „Dziennik Zachodni”, 25.03.2012, http://www.dziennikzachodni.pl/ artykul/384010,jan-miodek-dyskusja-o-jezyku-slaskim-w-pismie-jest-zenujaca,id,t.html [1.02.2018],

Jaroszewicz H., 2019, Krytyka prób emancypacji śląsczyzny. Plaszczyzna prawno-ustrojowa, społeczno-polityczna i personalna, „Slavica Wratislaviensia” CLXIX, s. 137-166.

Jeden śląski język odbierze Ślązakom ich godkę?, 2011, Wywiad z Heleną Synowiec, „Dziennik Zachodni”, 18.02.2011, http://www.dziennikzachodni.pl/artykul/370293, jeden-slaski-jezyk-odbierze-slazakom-ich-godke,id,t.html [1.02.2018]. 
Kadłubek Z., 2008, Listy z Rzymu, Katowice, Księgarnia św. Jacka.

Kadłubiec D., 2008, Nie wierzę w sztuczny, znormalizowany dialekt śląski, „Śląsk” 11 (157), s. 69.

Kik M., 2015, Filozofjo po ślōnsku. Czyli heft do historje filozofje dziadka Kika, Kotórz Mały, Silesia Progress.

Lubaś W., 2013, Studia socjolingwistyczne, Opole, Wydawnictwo Uniwersytetu Opolskiego.

Mańczak 1995, Czy istnieje kaszubski język?, „Język Polski” 75, 1, s. 33-41.

Mańczak W., 1996, Problemy językoznawstwa ogólnego, Wrocław, Zakład Narodowy im. Ossolińskich.

Mały słownik gwar polskich, 2010, red. J. Wronicz, Kraków, Wydawnictwo Lexis.

Markowski A., 2012, Opinia o projekcie ustawy o zmianie ustawy o mniejszościach narodowych $i$ etnicznych oraz o języku regionalnym, a także niektórych innych ustaw (Opinia zlecona), Biuro Analiz Sejmowych, 01.10.2012, http://orka.sejm.gov.pl/IEKSBAS.nsf/0/ C125768C004D7EE7C1257ACA00496714/\$file/i2207-12A.htm [1.02.2018].

Michna E., 2014, Odrębność językowa matych grup etnicznych i jej rola w procesach walki o uznanie oraz polityce tożsamości. Analiza porównawcza sytuacji Rusinów Karpackich i Śląaków, „Studia Humanistyczne AGH” 13/3, s. 115-130.

Miodek J., 2008, ...regionalność Śląska z jej językiem stała się wręcz modna, „Śląsk” 11 (157), s. 72.

Miodek J., 2012, Opinia o projekcie ustawy o mniejszościach narodowych $i$ etnicznych oraz o języku regionalnym, a także niektórych innych ustaw (Opinia zlecona), Biuro Analiz Sejmowych, 01.10.2012, http://orka.sejm.gov.pl/IEKSBAS.nsf/0/C125768C004D7EE7C 1257ACA004967DA/\$file/i2207-12A.5.htm [1.02.2018].

Mętrak M., 2017, Gwara? Godka? Język? Śląska tożsamość językowa w mediach elektronicznych, w: Młodzi o języku regionów, red. M. Kresa, Warszawa, s. 97-109.

Momot A., 2016, Gwara śląska jako tworzywo językowe „tlumaczeń” literatury światowej, „Socjolingwistyka” 30, s. 61-72.

Mowa śląska jest $w$ stanie udźwignać rzeczy metafizyczne, czy tylko relacje domowo-podwórkowe?, 2011, Wypowiedź Wojciecha Kuczoka, „Polska. Dziennik Zachodni”, 18.01.2011, s. 24.

Musioł J., 2008, Kodyfikacja zuboży tę wspaniała różnorodność i bogactwo gwary śląskiej, „Śląsk” 11 (157), s. 73.

Mutz S., 2008, Kodyfikatorzy chca stworzyć - na bazie istniejących dialektów - śląskie esperanto, „Śląsk” 11 (157), s. 73.

Myśliwiec M., 2013, Ślōnskǒ godka - przaśny folklor czy język regionalny?, „Przegląd Prawa Konstytucyjnego" 3 (15), s. 99-120.

Nadciagaja Ślązacy. Czy istnieje narodowość ślaska?, 2004, red. L.M. Nijakowski, Warszawa.

Nawarecki A., 2008, Nad gwarą śląska ciążyła anatema, „Śląsk” 11 (157), s. 74.

Nowakowska-Kempna I., 2008, ...uważam stworzenie jednego wspólnego dialektu ślaskiego za niemożliwe, „Śląsk” 11 (157), s. 75.

Nowy Testamynt po ślonsku, 2017, Podug Biblji Ks. Jakuba Wujka przełożoł Gabriel Tobor, Radzionków, Wydawnictwo Tobor.

O nauce i języku, 1997, Rozmowa Piotra Żmigrodzkiego z prof. Kazimierzem Polańskim, „Śląsk” 6 (20), s. 37-38.

Oddzielmy gware od polityki, 2008, Wywiad z Bogusławem Wyderką, „Nowa Trybuna Opolska”, 29.07.2008, http://www.nto.pl/opinie/art/4094197,prof-wyderka-oddzielmy-gware-od-polityki,id,t.html [1.02.2018].

Pańczyk-Pozdziej M., 2008, Ślaska gwara była i jest odmiana polszczyzny, „Śląsk” 11 (157), s. 76. 
Po naszymu, 2012, Wywiad Jacka Dziedziny z Marią Pańczyk-Pozdziej, „Gość Niedzielny”, 3 czerwca, s. 36-37.

Podgórska B., Podgórski A, 2008, Uznanie gwary śląskiej z pewnościa przyczyni się do konsolidacji Ślązaków, „Śląsk” 11 (157), s. 76.

Sekuła E.A., 2009, Po co Ślązakom potrzebny jest naród? Niebezpieczne zwiąki między autonomia i nacjonalizmem, Warszawa, Wydawnictwo Akademickie i Profesjonalne.

Semik T., 2010, Zdrzadełko z Bonanza, czyli VIPy mówia po śląsku, „Dziennik Zachodni”, 10.11.2010, http://www.dziennikzachodni.pl/artykul/334048,zdrzadelko-z-bonanza-czyli-vipy-mowia-po-slasku-wideo,id,t.html [1.02.2018].

Siuciak M., 2010, Język ślaski - problem terminologiczny czy społeczny?, „Białostockie Archiwum Językowe" 10, s. 267-277.

Siuciak M., 2012, Czy w najbliższym czasie powstanie język śląski?, „Poznańskie Studia Polonistyczne. Seria Językoznawcza" 19 (39), s. 31-44.

Skudrzykowa A. i inni, 2001, Gwara śląska - świadectwo kultury, narzędzie komunikacji, Katowice, Śląsk. Wydawnictwo Naukowe.

Stanowisko Rzadu wobec obywatelskiego projektu ustawy o mniejszościach narodowych i etnicznych oraz o języku regionalnym, a także niektórych innych ustaw (druk nr 27), 2015, http://www.sejm.gov.pl/Sejm8.nsf/druk.xsp?documentId=ABF5E5114F97107FC1257F5D004546D6 [1.02.2018].

Synowiec H., Cząstka-Szymon B., 2008, Każda gwara jest odmiana terytorialna języka ogólnonarodowego, „Śląsk” 11 (157), s. 79-80.

Szmeja M., 2017, Śląsk - bez zmian (?). Ludzie, kultura i społeczność Śląska w perspektywie postkolonialnej, Kraków, Zakład Wydawniczy Nomos.

Szczepańska E., 2013, Wizerunek Czecha w 'Zrób sobie raj' czy może kreowanie nowych stereotypów, „Bohemistyka” 4, s. 286-296.

Szołtysek M., 2008, Śląskość czy człowieczeństwo, to nie tylko świat dźwięków, „Śląsk” 11 (157), s. 79.

Ślōnski Kafka, 2016, Tłumaczenie aforyzmów Franza Kafki na śląski - Jerzy Ciurlok, Kraków, Wydawnictwo Akademii Sztuk Pięknych w Krakowie.

Tambor J., 2008, Autostereotyp i stereotyp Ślązaka, „Postscriptum Polonistyczne. Seria Językoznawcza" 1 (1), s. 81-97.

Tambor J., 2009, Propozycje kodyfikacji ortograficznej śląszczyzny, „Socjolingwistyka” 22, s. $83-92$.

Tambor J., 2014, Status języka a wola ludu i kodyfikacja. Przypadek ślaski, „Forum Lingwistyczne" 1, s. 37-49.

To nie jest język sztuczny, 2013, Wywiad Krzysztofa Karwata z Jolantą Tambor, „Fabryka Silesia" 2 (4), s. 15-18.

Ustawa z dnia 7 października 1997 r. o języku polskim, 1999, http://prawo.sejm.gov.pl/isap. nsf/DocDetails.xsp?id=WDU19990900999 [1.02.2018].

Ustawa z dnia 6 stycznia 2005 r. o mniejszościach narodowych i etnicznych oraz o języku regionalnym, 2005, http://prawo.sejm.gov.pl/isap.nsf/download.xsp/WDU20050170141/ U/ D20050141Lj.pdf [1.02.2018].

Wronicz J., 2013, Mowa Ślązaków - gwara, dialekt czy język regionalny (w związku z próba zmiany statusu prawnego), „LingVaria” 8, 1 (15), s. 173-184.

Wyderka B., 2011, Opinia o poselskim projekcie Ustawy o zmianie ustawy o mniejszościach narodowych i etnicznych oraz o języku regionalnym, a także niektórych innych ustaw (druk $n r$ 3835), Biuro Analiz Sejmowych, 30.04.2011, http://orka.sejm.gov.pl/IEKSBAS.nsf/0/ C1257806003D0075C12578A100265BC5/\$file/i334-11A_htm [1.02.2018]. 
Wyderka B., 2014, O rozwoju polskich dialektów, „Poznańskie Studia Polonistyczne” 21 (41), z. 2, s. 103-113.

Zasada M., 2018, Śląski język regionalny: piąte podejście. Dzisiaj do Sejmu trafi projekt ustawy o śląskim języku regionalnym, „Dziennik Zachodni”, 11.01.2018, https://plus.dziennikzachodni.pl/wiadomosci/a/slaski-jezyk-regionalny-piate-podejscie-dzisiaj-do-sejmu-trafi-projekt-ustawy-o-slaskim-jezyku-regionanym,12837358 [1.02.2018].

Zaręba A., 1987, Literackie języki regionalne w Polsce?, „Język Polski” 68, 2-3, s. 76-86.

HENRYK JAROSZEWICZ

\section{Criticism of attempted emancipation of the language spoken in Silesia - the academic (linguistic) aspect}

\section{Summary}

Despite the numerous attempts made in the 21 st century at gaining linguistic independence, the Silesian ethnolect still enjoys the official status of a dialect. Lack of success in the attempted emancipation should be attributed to the linguistic policy adopted by the Polish authorities and political elites. The attempts at emancipation of the language spoken in Silesia have been subjected to criticism on many levels of the social discourse including the academic level. However, a detailed analysis of the presented arguments is evidence that there are no objective, linguistic premises that questioning promotion of the Silesian ethnolect to the status of a regional language is unsubstantiated.

Keywords: Silesian ethnolect, Polish language, linguistic policy, language standardisation 